\title{
PARTICULARISM AND UNIVERSALISM IN THE LINGUISTIC THEORY OF SAADIA GAON *
}

ARON DOTAN

Tel-Aviv University

The life-work of Saadia Gaon in the field of language is not new to us; despite the fact that his main work on Hebrew grammar has not yet been published, we know something of it from extracts which have already been published, and from summaries of those parts that have not '.

Saadia appears, to an educated person of our generation familiar with the history of Hebrew grammar in the Middle Ages, to be a highly unusual grammarian. He was of course the first Hebrew grammarian, and deserves the credit for his pioneering work, but as a result his theories are far removed from those of his successors, which are today accepted by all, and which form the basis for contemporary normative grammar. Inasmuch as the work of Saadia preceded all grammar that is by common consent considered «scientific", not only is his presentation unusual, but sometimes his work even appears strange and naive. What he presents as grammar seems to us to be more like the groping search of a scout at the frontier.

As a result, and also because those of his writings which deal specifically with grammar were not available to us, we were unable to evaluate his contribution appropriately. Because we were looking at it through the mirror of the grammatical theory that sprang up

* Parts of this paper were read (May 1993) at a gathering on Medieval Hebrew Linguistics on the occasion of the inauguration of the Jacob and Shoshanna Schreiber Chair for the History of the Hebrew Language at Tel-Aviv University.

I A. HARKAVI, «II. N2 8. שישנים (1906) 26-40; S. L. Skoss, "A Study of Inflection in Hebrew from Saadia Gaon's Grammatical Work 'Kutub AlLughah'", JQR N.S., 33 (1942-1943) 171-212; IDEM, "A Study of Hebrew Vowels from Saadia Gaon's Grammatical Work 'Kutub Al-Lughah'", JQR N.S., 42 (1951-1952) 233-317; IDEM, Saadia Gaon, The Earliest Hebrew Grammarian, Philadelphia 1955. See also A. SÁnz-Badillos, Historia de la Lengua Hebrea, Barcelona 1988, pp. 214218. 
after his time, rather than as an independent entity not to be compared with later theory, we could not plumb the depths of his thought nor grasp the breadth of his horizons.

Now, for the first time, as I prepare a critical edition of his great linguistic treatise כתאב פציח לגה אלעבראניין (Kitāb fașịh luḡat alcibranniyyin: The Book of the Elegance of the Language of the Hebrews), I am able to study his grammatical doctrine at first hand and in depth, and to throw light on hitherto unknown aspects. I say "his doctrine", and this is in itself an important statement, since it implies the existence of an ordered and systematic theory of the language. We are no longer speaking of gropings and half-truths and crumbs of knowledge, as people had become accustomed to ascribe to him, but of a solid and systematic theory revealing order and regularity in the language. Or so it would seem. It does not seem to be the pioneering work of an innovator, with all the doubts and hesitations involved, but rather a system of certainties and wellfounded, well-ordered facts, as though Saadia had been preceded by generations of scholars who had thrashed out the subjects with which he deals, struggled with them, and finally conquered them; or as if he is but the gatherer of a sheaf after the harvester, and is presenting the ready-organized doctrine of earlier scholars, he himself having come along to reap the benefits. This, however, is not the true situation. Saadia was the pioneer, an original creator, who in his work not only established the first set of grammatical rules for the Hebrew language, but in so doing also created the very discipline known as Hebrew grammar. As in all other fields of his endeavours, in this field too the title of "the foremost speaker in every area", as Abraham Ibn Ezra crowned him at the beginning of his Sefer Moznayim, is appropriate. Despite this, a thread of modesty pervades his work; the innovation in it is not underlined, nor is there any indication of the originality of his grammatical endeavour, nor any trace of glorification or boasting, any of which we might have expected to find and which would have been understandable - but there is none.

Much has already been said on the subject of the comparison between languages that was the heritage of the Hebrew grammarians of the Middle Ages, such as Saadia Gaon, Yehuda Ben Quraysh, Dunash Ben Labraț, Yona Ibn Janāh and others; it was even accepted as a self-evident phenomenon that only Jews were active in 
this field of comparison, since the educated among them were polyglots, familiar with a minimum of three languages; they spoke Arabic as did any civilized person, and Hebrew and Aramaic fell to their lot as a private heritage.

Although Saadia was the first in this field as well, a pioneer in language comparison, his conceptual thinking about languages and his approach to them were special and unusual compared to those of his successors. At his hands, the Hebrew language was crowned with an exclusive crown, and enjoyed deep and detailed observation, as would be expected of a grammarian describing a language. Yet, at the same time, Saadia succeeded in seeing the Hebrew language in the broad context of human language in general, even more than in that of the languages with which he compared Hebrew directly. Saadia took an additional step beyond language comparison in that he perceived not only the elements common to the languages he compared, but also linguistic universality. He ascribed to the generality of human language certain of the properties common to the languages he compared, and made inferences from these findings about the universality of language. In this he was not only the first of the Hebrew grammarians, but in fact quite unique. It is clear from his writings that the phenomenon of human language as such interested him no less than the grammar of a specific language.

There is no denying that Saadia, like most of the grammarians of the Middle Ages who followed him, drew on Arab sources. He was well versed in the theory of Arabic grammar, and it was probably the example of the Arabic grammarians that inspired him to lay the foundations of Hebrew grammar. In this Saadia was no different from the later Hebrew grammarians, but there lay a difference in the way he chose to distinguish himself from his Arab mentors.

It is worth considering the position of the Jewish scholars in the midst of the surrounding culture, how they felt about it, and their modes of thought. It is only natural that some would wish to learn the ways of the dominant culture, to become infected with them and to imitate them, and to draw their own culture closer to the surrounding culture. On the other hand, it is safe to assume that there would be others who would choose to preserve their unique Jewish identity; yet even these would be affected, without their wishing it, 
by the patterns of thought and the modes of behaviour of the gentile environment in the midst of which they lived.

It was not only the urge to write books on language that Saadia acquired from the Arabs. He was also versed in their doctrines of language, and he was completely familiar with their grammatical tenets, both of practical grammar and of theoretical linguistic thinking, philosophy of language, and axiomatic questions concerning the origins of language - all these he imbibed and passed on in his book, to the great benefit of the study of the Hebrew language. This in itself lent to Saadia's writings a certain measure of generalization in language, of the study of general linguistic theory reaching to the foundations of language as a vehicle of human expression. In this endeavour, Saadia sometimes went beyond the conceptual framework of his Arab teachers and, in so doing, laid the foundations for the field of general linguistics.

This strong desire to uncover the elements common to all languages and to examine the special mechanism of language, of every language, as man's vehicle of expression, is evidenced at the outset of the discussion each time Saadia treats a fresh grammatical subject.

Thus, for example, in the Hebrew introduction to Sefer ha'Egron he speaks explicitly about his fundamental method: ${ }^{2}$

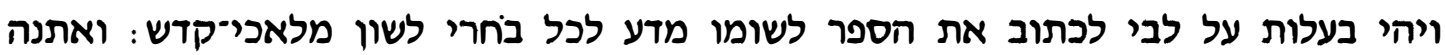

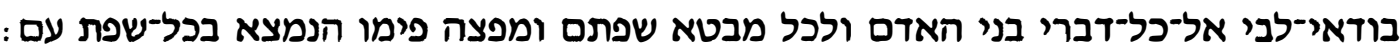

When I decided to write the book to give knowledge to all who have chosen the language of the holy angels: I thought about the speech of man and all the pronunciation of their lips and uttering of their mouths found in all the languages of the nations.

So it is clear that he gave careful consideration to human speech (parole) in general as embodied in every language.

He followed the same path in the treatise on grammar mentioned above. Saadia's constant alertness to the situation in other languages comes to the surface from time to time in the course of discussions on various topics. In the seventh chapter, for example, where he

${ }^{2}$ N. Allony, חאגרון - כתאב אצול אלשער אלעבראני, מאת רב סעדיח גאון, Jerusalem 1969 , p. 160. 
discusses the ways of extending the pronominal accusative suffix of the third person verbal form, he presents the four possibilities

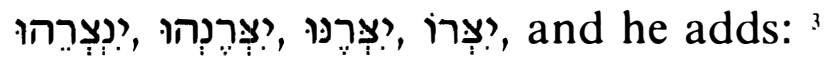

והדא זואיד ללעבראני עלי כל לגה ממא ערפנאהא

and these [letters] are additional in Hebrew beyond [those of] any other language known to us.

He is awake not only to matters of grammar, but also to those pertaining to the pronunciation of the spoken word, and he gives a phonetic analysis of sounds existing in the pronunciation of speakers of other languages. In his commentary of Sefer Yessîrâ $(2,2)$ he describes the Arabic sounds לאם, גים, טא , צאד, ('thickened' as in the Arabic word Allah), the Persian shin, the special pe in the word אַפַּד (Daniel 11:45), and in fact relies for matters of Arabic on one of the books written by the Arabs (בעץ כתב לגה אלערב).

It is, however, in the opening of the various chapters of his work on grammar כתאב פציח לגה אלעבראניין that Saadia's awareness is especially marked. These opening sections sometimes appear to be a theoretical introduction to the matters discussed in the body of the chapter.

Although eight chapters of this work are wholly or partially extant, only five of the opening sections have come down to us in their entirety: the third, fourth, fifth, seventh and eighth. The seventh and eighth deal with a phenomenon peculiar to Hebrew - the special nature of the gutturals and the vowel changes in their vicinity - and therefore in these chapters no parallel with Arabic can be expected. Matters are different in the opening sections of the remaining chapters.

For example, in the opening to the third chapter, on inflection, he writes:

The rules and fundamentals of this part are not relevant just to the language of the Hebrews, but to all the languages known to us... As to this part, it is devoted entirely to facilitating the study of any known language, and only very little of it applies to Hebrew alone.

${ }^{3}$ All quotations here and below are from the critical edition of Saadia's Grammar in press. 
In this way Saadia introduces the five premises that are fundamental to every language (known to him); among his basic premises he includes the division of words into the three categories: nouns, verbs, particles - an approach with its origins in the thought of ancient Greece, and a basic precept of Arabic grammar.

Indeed, in the continuation of this chapter, when Saadia gives tables of the conjugation of the verb, he sets them out in both languages. The Arabic conjugation table is not presented here as a translation of the Hebrew, but rather as a parallel to the Hebrew conjugation table. It is not a text and translation that we have here, but two parallel tables that are compared with each other. This is an innovation in Arabic as well. It is the first conjugation table in Arabic grammar ${ }^{4}$.

In the fifth chapter, on the vowels, he says:

And before we mention what of this knowledge (of the vowels) is special to the language of the Hebrews, we shall refer to that in the knowledge of vowels which is common to all languages.

After formulating the four premises concerning vowels which apply to all languages, he concludes:

And since we have already mentioned these four general premises, it is now time to present that which is special to the language of the Hebrews.

These general premises (אלעאמיאת) deal with the universal question of the definition of the phonological structure of a syllable and its various types - clearly a matter of general linguistics, and relevant to languages in general. Nor are the examples of the different types of syllable taken from Hebrew; in the third premise, for example, the Arabic examples מצחף ,ארץ, סמא are used.

Another weighty question cardinal to linguistic thought throughout the ages occupied the mind of Saadia Gaon, and that is the question of the origin of human language.

"As E. Goldenberg has already pointed out, cf. "לוּח הנטייה חעברי הראשוֹ", Leshonenu 43 (1979) 83-99, 87. 
The ancient controversy among the early Greek philosophers on this subject is well known: is language natural, with an inherent and organic mutual relationship between objects and their names, which were part of the objects by nature ( $\varphi$ vi $\varepsilon \imath$ ), and therefore each object can have only one correct name, and there is no room for change in language, as Plato held? Or is language a matter of convention ( $\sigma u v \theta \eta \dot{\kappa} \kappa)$, objects having acquired names by consensus among people, in which case language is open to change and development, which are legitimate as long as people have agreed to them, as Aristotle opined?

These questions concerning the correspondence of the word to the idea signified had been transferred from Greek philosophy to the seats of learning of the Islamic scholars; moreover, the ancient disputes, which had died down after more than a millennium (from the time of Plato and Aristotle in the fifth and fourth centuries B.C.E.), recurred in full force in the ninth century C.E., and occupied an important place in the world of Arabic scholarship, not only among scholars of language but also, and to an even greater degree, among theologians and philosophers.

Saadia, as we said, was steeped in Arabic culture and in the questions with which it was concerned, and it is little wonder that he was preoccupied with the same questions, and sought solutions for them. As was his wont in other matters, in this matter too he accepted the ways of thought and analysis followed by gentile scholars, adapting them to his own needs, that is, to the Hebrew language and to the attitude which lies at the base of his linguistic and theological thinking. Since he was not limited by the shackles of Islamic religious beliefs, he could follow paths which Arab scholars could not.

Let us take a look at what he has to say on this. In two places in his work כתאב פציח לגה אלעבראניין he raises the question of the origin of language, in the fourth chapter and in the seventh chapter, with different emphases in each.

In the first passage, from chapter four, he discusses dageš and rafeh, and examines in detail the category of "unmotivated dages"». Saadia illustrates the unmotivated dages with the pairs

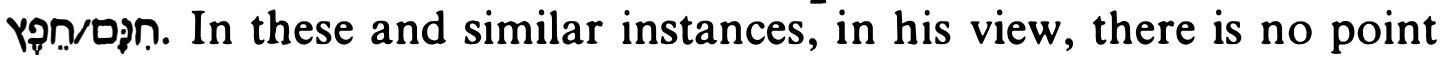
in seeking a reason for the dages or the rafeh, since these were laid down by the «institutor of the language" (ואצע אללגה), just as it was 
he who was responsible for the establishing of names for the objects signified, and in his hands lay the reason why, for example, Arabic יום is (day) whilst Arabic יזם is (sea). We, the speakers of the language, have received these in the form in which they were fixed; they have reached us as a result of convention (אצטלאח), and not as a matter of choice. The choice (אכתיאר) lay in the hands of the institutor of the language. What he determined was upheld by consent, and we received what was handed down. Just as the institutor of the language determined the nouns, so he determined the vowels in the words, and the dages. And just as we agree to accept the nouns, so we agree to accept what has been determined in the case of the vowels and the dagers.

In the seventh chapter, Saadia presents the changes which occur in the triliteral verb when one of its letters is "או. When the first letter is yôd, the initial vowel is sometimes hîreq (אירֵש, etc.) and sometimes șêrê (אֵֵָ, etc.). To the question of the reason for this difference in the vowel, and what the rule is, he replies with a long discussion, in which he disputes the view that the nouns are determined by nature, and reveals his firm opinion (and here I quote the essence of what he says) that the nouns were determined by consensus among people, who gave a name to every object existing in reality. The name is not, therefore, an inevitable outcome of the meaning of the object, for if the meaning of the object were to demand a specific name, there could be no difference between the languages of man, nor could an object be called by different names in different languages. Thus, for example, it would be necessary for אבן (stone) to be called not חגן Arabic also. Since every object has a different name in each language, there is proof that the names are not determined by any intrinsic meaning of the physical object, but are rather the result of consensus (אצטלאח) among people, and in every language a different name was agreed on. Just as in any given language a certain name was agreed on for an object, they could equally well have chosen a different name for the same object. Thus everything depends on convention. For that reason there is no point in seeking reasons for the words themselves, nor for their form or their pronunciation. Both the letters and the vowels are the outcome of convention among people, and there is no reason to be sought. This was Saadia's opinion.

Thus Saadia talks mainly about convention among people. It is 
they who have determined a name for every real object, and the name is not the inevitable outcome of the essential nature of that object. From here it is a natural progression to the concept of the arbitrariness of the linguistic sign, a concept familiar to the Arabs as well. It might be said that Saadia is of the opinion that the linguistic sign is arbitrary, although of course we should not expect to find in his writings actual Saussurean terminology of this nature.

Inasmuch as it is clear to Saadia that language is a matter of convention, he makes a point of warning against anarchy in language. Convention is not in the hands of just anyone, and certainly not of the current speaker of the language, but is handed down from earliest antiquity. It is here that he introduces the idea of the 'institutor of the language', who determined the names. The institutor of the language is not a specific person, and certainly not a deity, but an anonymous being (a man or a group of men) from the time of the origin of language. It was the institutor of the language who chose the names for the objects in an arbitrary manner, then gave to his choice a dimension of immutability, about which consensus among people was achieved, and this consensus is transmitted from generation to generation.

Saadia's succinct formulation in the second version of chapter four, at the point where he discusses the unmotivated dages, is particularly apt:

לא עלל להא אכתר מן אלאחאלה עלי אכתיאר ואצע אללגה מן אלאצל

they have no reasons beyond the tradition according to the choice of the institutor of the language in the beginning.

His outlook can be summarized, then, in stages:

1) The choice made by the institutor of the language (אצעע) (אללגה) is arbitrary.

2) The result of the choice (אכתיאר) is fixed (וצע) in the language.

3) What has been fixed becomes a convention (אצטלאח).

4) What has been fixed is handed down from generation to generation (אחאלה , אנתקאל).

Thus the convention is from before our time, and by force of tradition we are obliged to adhere to the names and may not alter them. 
The study of Saadia's works reveals to us not only his deep knowledge of the linguistic opinions of the contemporary Islamic world, but also his general linguistic thinking, surprising in its closeness to modern thinking. We have already noted that even in the first passage we are able to discern the concept, which in our generation is ascribed to de Saussure, of the arbitrariness of the linguistic sign, a concept familiar to the Arabs as well. In the second passage, not only is the impression strengthened, but there is in addition a pair of terms, עלאמאת (signs), אשיא (objects), one of which at least is astonishing in its closeness to modern linguistic terminology, reminding us of the pair 'sign' and 'signified' (signifiant - signifié) denoting the name, the word, as opposed to the object (אלשי) it signifies.

Our claim is that Saadia was well versed in the linguistic knowledge of his time, was influenced by it, and also added his own input, both in terminology and in original thinking.

When Saadia ascribes the establishing of names to ואצע אללגה there is no doubt that he is referring to Adam, the first Man, he who, according to the Biblical story, was the one to give names to every creature: "... and brought them unto Adam to see what he would call them: and whatsoever Adam called every living creature, that was the name thereof. And Adam gave names to all cattle, and to the fowl of the air, and to every beast of the field..." (Gen 2,1920). Similarly, we find Adam giving a name to his helpmeet (woman, Gen 2,23) and חin (Eve, Gen 3,20). Nevertheless, in the two passages discussed above, Saadia does not expressly state that he is referring to Adam, preferring to use the general appellation ואצע. It would seem that he did this in order to lend to what he had to say a general nature, appropriate to any language and not only to Hebrew. Both passages are imbued with the stamp of a general approach to language and, apart from the examples, which are naturally taken from Hebrew, they are applicable to any language. This is yet another instance of the universality of Saadia's thinking in matters of language.

In fact, it is inconceivable that Saadia should have held opinions differing from those found in the Tora. He held firm to the idea that Adam's language was Hebrew, and said so explicitly in his long commentary to Genesis : 67.

${ }^{3}$ Quoted from M. Zucker, Saadya's Commentary on Genesis, New York 1984, p. 
ובאי לגה סמאהא בלשון הקודש לאנה אלמתרצי ואלמذתאר

And in which language did he name them? In the holy tongue, for that was the accepted and chosen language.

In any case, all the name-giving ascribed to Adam was in Hebrew.

But even there, in the description of the creation, and the creation of language, Saadia speaks about the general phenomenon, about the property of speech in man. He does not call this לגה, which means a specific language, but כלאם, meaning human speech. He explains the above verses from the Book of Genesis thus ":

כדלך למא כנא לם נשאהד כלאמא אלא תלקינא ען סאבק סבקנא עליה פתעלמנאה מנה

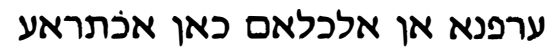

Moreover we see language strictly as something passed down to us by our forebears, and accordingly we understand that language came into being as an original creation.

(כלאם here means 'creation, divine creation', and is therefore a divine creation. Yet there is a difference between כלאם, which is the property of human speech, and לגה, which is the substance of language, a specific language.

According to Saadia, it was God who gave man the power of speech, and therefore also the speech sounds. Saadia calls God מולף אלכלאם (the composer of speech), and from Him are derived the 22 letters, as he says at the end of the seventh chapter of his Grammar:

כלהא למא כאנת אלכב חרף מוצועה בין ידי מולף אלכלאם מן אצל אסאס אללגה פולף מן

When the 22 letters were put before the composer of speech from the basic components of language, speech was composed using them all.

Speech was composed from the letters, and they are the foundations of the language and from them were made the words.

On the other hand, the ואצע אללגה referred to in the passage

${ }^{6}$ M. ZUCKER, op. cit., pp. 65-66. 
quoted above (p. 7) is the creator of language who introduced the words, and everything said in the passage is relevant to his deeds the choice of names, their immutability, the consensus about them, and their transmission throughout the generations. לגה, then, is the substance of the language, a specific language, and the naming process - that is determining the words which form a language - is carried out by man. In the two passages quoted, Saadia discusses לגה, the language itself - the Hebrew language and at the same time any other language in the world.

The old Greek dispute about the origin of language took a different course under the Arabs, and became a burning theological issue. The two poles of the dispute were no longer "language by nature", versus "language by convention". The religious thought of Islam could not contemplate the possibility that language was not God-given, and "by nature" was in practice interpreted as "from the hands of God", for what could be more a matter of nature than God himself?

Indeed, to begin with, this question was the province of the Arab theologians and philosophers, and it was they who saw in it an important subject in which to excel. The basic questions about the nature of language, its origins and the way in which it came into being, were among the fundamental issues in their thought, and thus we find Islamic philosophy and faith in the eighth and ninth centuries concerned with these very questions?. Arab linguistic scholars at first confined themselves to language proper, to pronunciation, forms, grammar and lexicon, and avoided theoretical questions about the origin of language. It is only in the tenth century that Arab linguists begin to take an interest in these questions. However, by the time they started to deal with these questions from a linguistic viewpoint, the debate about these same questions in the other disciplines was already far advanced, and a number of schools of thought had established themselves. Linguists neither wanted nor were able to ignore the views which had crystallized in the course of time in the fields of thought and religion; but when accepting them, they also had to accept the disputes accompanying them, disputes which had not arisen in the field of linguistics and maybe would

\footnotetext{
7 See H. LouCEL, "L'origine du langage d'après les grammairiens arabes", Arabica 10 (1963) 188-208.
} 
never have done so at all if the discussion had developed in that field alone.

The view that language was God-given thrived among scholars of religion. As God-fearing men, they could not ignore the basic tenets of Islam, according to which it was unthinkable that language was the work of man. They supported their claim. too, with a pas-

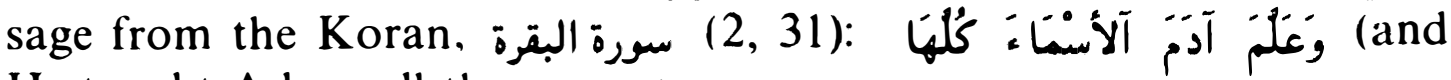
He taught Adam all the names).

According to the interpretation of adherents to this school of thought, that of divine determination (توقيف) or divine inspiration ( الهام ) *, God taught man the names of all creatures and everything in existence, and in so doing gave him language. This view, totally imbued with the spirit of Islamic religious principles, was widespread, and could be heard from the mouths of the greatest thinkers of the time ", who were supported by a weighty tradition and the highest authorities. Thus, for example, Abū Alḥasin Aḥmad Ibn Fāris (9181004; spent part of his life in Baghdad), relying on the Koran, held that language is توقيف, and based his opinion on Ibn 'Abās (d. 687), a cousin of the Prophet, and very close to him.

Opposed to this school were those who supported the idea of convention ( اصطلاح); according to them, language is a human invention, people having reached agreement about the meaning of words and their use in language ". This view was held mainly by the $M u^{\prime}$ tazila and the philosophers, who were influenced by the theories of Aristotle - for instance the scholar and writer of Adab literature, 'Omar Ibn Bahr Aljāhiz (d. 869), or the renowned philosopher and Aristotelian commentator, Abū Nașr Alfārābī (d. 950).

Saadia was well versed in the linguistic knowledge of his time, was influenced by it, and also added his own input, both in terminology and in original thinking, and sometimes went further, and we might even say to a greater depth than did his Arab contemporaries; he was able to do so because he was not bound as they were by the dogmas of Islam.

${ }^{8}$ On the distinction between these two concepts see R. Arnaldez, Grammaire et théologie chez Ibn Hazm de Cordoue, Paris 1956, p. 39.

${ }^{9}$ On the various views and their distribution among the different schools see $\mathrm{L}$. KOPF, "Religious Influences on Medieval Arabic Philology", Studia Islamica 5 (1956) 33-59, 56.

${ }^{10}$ This concept, too, and its cognates are discussed by R. ARnaldez, loc. cit., and by L. KOPF, op. cit., p. 57. 
He accepted the concept of ואצע אללגה (institutor of the language), but did not necessarily relate it to God. He conceived the institutor as the primeval generator of the language, a creator whose determinations were accepted by the people, and that is what constituted convention. "The institutor of the language" was anonymous, and apparently human - Saadia is not explicit, but it is clear that the institutor was primeval, and that language goes back to him. The institutor of the language is not, then, a divine being. It is he who determined the language, which was then accepted by all people.

The Islamic scholars were interested mainly in the Arabic language and adhered to the Koran, whereas the writings of Saadia are formulated as generalizations and they apply to all languages, or to human language in general, and not to the Hebrew language in particular, although he saw in Hebrew the first language. Indeed, in his Hebrew introduction to Sefer ha-'Egron he says as much: "The book 'Egron for the Holy Tongue, which God chose from time immemorial". Chosen - yes: but nothing about creation.

In the very way, however, in which Saadia demonstrates convention in language, universal linguistic considerations are given marked prominence; we have already seen how he treats these considerations at length and bases the reality of language by convention on the difference between languages, that is, on the fact that the same objects have different names in different languages. In the prominence he gives to this, Saadia goes even further than the Arabs.

With this we can sum up Saadia's contribution to ancient thinking on the subject of how language came into being. Although he refrains from being bound by the obligations of Islamic faith, and as a result prefers the Aristotelian approach to language as being the outcome of convention, he does not entirely abandon the idea

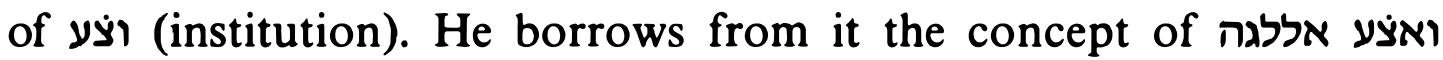
(the institutor of the language), which to most Moslems refers to Almighty God, and uses it to clarify the concept of convention, which cannot be conceived of as a one time event. Convention, too, started from some point in the distant past, and is the work of the anonymous institutor of the language. It was he who chose the words and fixed them, and from him they were accepted by convention for the use of people.

Moreover, Saadia succeeded in presenting his views in a diachronic dimension, as a process in which the transmission from 
generation to generation has a part to play. It is tradition that preserves the purity of the language. In this his outlook goes further than that of the Arab אצטלאח school.

This concept is vitally important for Saadia's theories, because otherwise language as consensus between people would amount to anarchy, and people could agree to one thing today and another tomorrow. That in fact is the primary weakness in the arguments of those who support convention as opposed to those who favour divine revelation. The latter have only to cleave to the words of God: it is impossible and inadmissible to alter them (and from this point of view they are no different from those who held the Greek concept that language is by nature); but what are the former to do? It fell to Saadia to add the dimension of tradition, revered by all, certainly by the Jews, and, moreover, this dimension is compatible with the Masora linked with the Biblical text, from which it receives and to which it in turn lends support. With the help of the notion of tradition (אנתקאל), Saadia redeemed the notion of convention in language from the realm of the present and enhanced it with the splendour of ancient times, in order to preserve the language from possible harm at the hands of its speakers.

Again we see the greatness of Saadia as a linguist and an enlightened thinker, innovative and well versed in current disciplines, who in his book on grammar confirms the accepted ideas of the linguistic scholarship of his time, adapts them with creative originality to the needs of the Hebrew language, and adds to them a dimension of universality. 


\section{RESUMEN}

Como iniciador y generador de la gramática hebrea, Saadia Gaón (882-942) dependió de la escuela gramatical árabe. Seguidor del pensamiento y tendencias lingüísticas de los árabes, tomó de ellos prestado gran parte de su método y terminología gramatical, que aplicó, con los cambios necesarios, al hebreo. Fue el autor de la primera gramática, Kitāb fașīh luğat al-ibrāniyyīn, en la que expuso los fundamentos de la estructura gramatical hebrea. Su tendencia universalista se puso de manifiesto en su estudio comparativo de la lengua, campo en el que fue pionero, superando a sus modelos árabes. Centró su atención en los rasgos lingüísticos comunes a todas las lenguas, en especial las de su propio medio cultural: hebreo, árabe y arameo. Saadia demostró también su familiaridad con las teorías contemporáneas relativas al origen del lenguaje. Donde los árabes habían conseguido logros considerables, él fue más allá mostrando así su originalidad.

\section{SUMMARY}

As the originator and generator of the discipline of grammar in Hebrew, Saadia Gaon (882-942) was dependent on Arabic grammatical scholarship. He followed the Arabs' linguistic thought and approach to language, and from them he borrowed much of his grammatical method and terminology, applying it with the necessary changes to Hebrew. He was the author of the first Hebrew grammar Kitäb fassih lug $\bar{g} a t$ al-ibräniyyin, in which he laid down the foundations of Hebrew grammatical structure. His universal approach made itself manifest by his language comparison, a field in which he was a pioneer surpassing his Arab models. He focussed his attention to linguistic traits common to all languages, specifically to those of his own cultural milieu: Hebrew, Arabic and Aramaic. Saadia also showed his familiarity with the contemporary theories regarding the origin of language. However, even there, where the Arabs had attained considerable accomplishments, he went a few steps beyond them and showed his originality. 